\title{
PENGEMBANGAN KOMPONEN KOMPETENSI KEWARGAAN DALAM BUKU TEKS PENDIDIKAN KEWARGANEGARAAN SMP/MTs
}

\author{
Dikdik Baehaqi Arif \\ Program Studi PPKn FKIP Universitas Ahmad Dahlan \\ e-mail: dikdikbaehaqi@ppkn.uad.ac.id
}

\begin{abstract}
This essay was aimed at describing the development of civic knowledge, civic skill and civic disposition on textbooks for junior high school namely "Belajar Memahami Kewarganegaraan 1, 2 and 3". Based on content analysis, it can be conducted that civic education element was developed through teaching material presented accompanied by features, such as additional boxes, every chapter including pictures, law corner, info, public figures, and citizenship dictionary. In addition to presentation of civic skill related teaching material, box of "uji kompetensi" was utilize to enhance civic skill competences. Civic disposition was enhanced by inserting national values as well as up-held-values but conceptually.
\end{abstract}

Keywords: civic education, text book, civic competences

\section{PENDAHULUAN}

Buku teks (textbook) memiliki kedudukan yang strategis dalam proses belajar mengajar. Sebagai jenis buku yang diperuntukkan bagi peserta didik untuk bekal pengetahuan dasar sesuai bidang ilmu, buku teks ini sering menjadi acuan sekaligus sumber belajar yang utama. Bahkan buku teks bukan hanya menjadi rujukan para peserta didik, tetapi juga menjadi acuan utama para guru dalam praktik pembelajaran. Besarnya ketergantungan ini menuntut tersedianya buku teks yang berkualitas, baik dilihat dari segi isi materi (content), pedagogis dan keterbacaan (readability). Sehingga buku teks benar-benar dapat memfasilitasi siswa untuk belajar mandiri, mengembangkan daya nalar, keterampilan, dan lebih jauh membentuk sikap atau watak peserta didik.

Dewasa ini, untuk memenuhi ketersediaan buku teks setiap mata pelajaran, pemerintah melalui Kementerian Pendidikan Nasional (kini Kementerian Pendidikan dan Kebudayaan) menyusun kebijakan perbukuan nasional berupa Buku Sekolah Elektronik (BSE). Kebijakan yang menyediakan buku pelajaran dalam bentuk file yang dapat diunduh gratis itu di satu sisi dapat meringankan beban orang tua dalam pengadaan buku, tetapi di sisi lain, ketersediaan BSE itu 
tidak dapat dijangkau sepenuhnya oleh sebagian besar peserta didik karena keterbatasan sarana dan prasarana, seperti komputer dan akses internet.

Bahkan dalam pandangan Abdulkarim (2010) permasalahan buku teks tidak berhenti pada keterbatasan sarana dan prasarana untuk mengakses buku teks tersebut, tetapi juga pada kualitas buku teks yang tidak dapat memandu proses pembelajaran di kelas. Karena itu, pada beberapa kasus, guru tidak menggunakan buku teks yang ada walaupun telah direkomendasikan (lulus penilaian) Pemerintah.

Idealnya, buku teks tidak hanya melakukan transfer pengetahuan (knowledge), tetapi juga keterampilan (skill) dan sikap (attitude) yang dapat merangsang siswa untuk melakukan perubahan perilaku dan mampu membentuk pandangan dunia (world view) siswa, termasuk di dalamnya cara pandang siswa dalam memahami dan menyikapi realitas kehidupan nyata berbangsa dan bernegara (Abdulkarim, 2010). Sudahkah buku teks yang ada memenuhi ketiga aspek itu? Hal ini patut dilakukan analisis. Sebagai contoh, dalam konteks buku teks Pendidikan Kewarganegaraan, penelitian yang dilakukan Abdulkarim (2006) pada beberapa SMA di Kota Bandung menyimpulkan bahwa secara taksonomi, pada hampir setiap buku teks lebih cenderung pada aspek pengetahuan (knowledge). Buku teks PKn belum memiliki muatan materi yang dapat memotivasi, merangsang, dan melatih kemampuan berpikir siswa kadar tinggi. Buku teks PKn masih belum mengakomodasi tuntutan pembelajaran yang berpusat pada siswa (student centered learning) yang tampak pada penyajian materi yang belum mendorong siswa untuk belajar pada pusat-pusat kegiatan warga negara, mengamalkan isi pembelajaran, dan memacu keingintahuan siswa. Begitupun dalam penyajiannya kurang mendorong kesadaran politik dan hukum, kepedulian sosial, cara berpikir kritis, dan kesadaran adanya kemajemukan kehidupan masyarakat dan bangsa Indonesia.

Beberapa temuan di atas menunjukkan bahwa masih terdapat permasalahan dalam penyajian buku teks PKn. Diantarnya adalah pada aspek isi (content) yang baru menyajikan transfer pengetahuan (knowledge) saja, dan belum banyak menyajikan aspek afektif dan psikomotor. Dalam konteks isi inilah penelitian ini akan dilakukan. Penelitian ini memfokuskan diri untuk menganalisis buku teks 
PKn tingkat SMP/MTs pada aspek isi (content). Isi yang dimaksud adalah kompetensi kewargaan yang merupakan komponen PKn.

Penelitian yang dilakukan IEA terhadap implementasi PKn di 28 negara secara umum menyimpulkan bahwa komponen PKn meliputi aspek civic knowledge, civic engagement, dan civic attitudes serta konsep lainnya (TorneyPurta, et.al, 2001:179). Adapun materi PKn yang diteliti meliputi materi demokrasi, kewarganegaraan, identitas nasional, hubungan internasional dan keragaman/kohesi sosial (Torney-Purta, et.al, 2001:29-30).

Patrick dan Vontz (1999:34; 2001:4) mengelompokkan komponen kompetensi kajian kewargaan menjadi empat, yaitu (1) knowledge of citizenship and government in democracy (civic knowledge); (2) cognitive skills of democratic citizenship (cognitive civic skills); (3) participatory skills of democratic citizenship (participatory civic skills); dan (4) virtues and dispositions of democratic citizenship (civic disposition). Dari keempat komponen itu, Patrick dan Vontz (2001:46) menjabarkan ke dalam materi pokok kajian pengetahuan PKn menjadi tujuh topic, yaitu (1) demokrasi perwakilan (representative democratic); (2) konstitusionalisme; (3) hak asasi (liberalism); kewarganegaraan (citizenship); (5) masyarakat kewargaan (civil society); (6) ekonomi pasar (free and open economic system); dan (7) tipe-tipe masalah publik. Tipologi komponen kompetensi tersebut oleh CCE (1994) dikenalkan dengan tiga komponen, meliputi civic knowledge (pengetahuan kewargaan), civic skills (keterampilan kewargaan, meliputi cognitive skills dan participatory skills) dan civic dispositions (watak kewargaan).

Berdasarkan latar belakang di atas, artikel ini mengkaji pengembangan buku teks Pendidikan Kewarganegaraan SMP/MTs terutama yang berkaitan dengan penguatan komponen kompetensi kewargaan. Fokus tulisan ini dilandasi kesadaran bahwa komponen kompetensi kewargaan sebagai isi buku teks, bukan satu-satunya komponen untuk menilai kualitas buku teks Pendidikan Kewarganegaraan SMP/MTs. Artikel ini berturut-turut membahas tentang pengembangan pengetahuan kewargaan (civic knowledge) dalam buku teks PKn SMP/MTs, pengembangan keterampilan kewargaan (civic skill) dalam buku teks 
PKn SMP/MTs, dan pengembangan watak kewargaan (civic disposition) dalam buku teks PKn SMP/MTs.

\section{METODE PENELITIAN}

Artikel ini diturunkan dari hasil penelitian kualitatif, seperti yang dikemukakan oleh Creswell (1998) yang menyatakan bahwa penelitian kualitatif adalah proses penelitian untuk memahami berdasarkan tradisi metodologi penelitian tertentu dengan cara menyelidiki masalah sosial atau manusia. Penelitian ini merupakan analisis isi (content analysis) sebagai salah satu tradisi penelitian kualitatif. Peneliti tidak menggunakan upaya kuantifikasi atau perhitungan-perhitungan statistik, melainkan lebih menekankan kepada kajian interpretatif. Teknik pengumpulan data melalui studi literatur dan studi dokumentasi.

Sumber data berupa Buku Teks Pendidikan Kewarganegaraan di SMP/MTs, serta buku-buku yang berkaitan dengan kompetensi kewargaan (civic competence). Selain itu digunakan pula sumber data lain, seperti jurnal, makalahmakalah dan sumber internet sebagai unsur penunjang penelitian.

\section{HASIL PENELITIAN DAN PEMBAHASAN}

\section{Pengembangan Kompetensi Pengetahuan Kewargaan dalam buku teks PKn SMP/MTs}

Pengetahuan kewargaan (civic knowledge) berkaitan dengan materi substansi yang seharusnya diketahui oleh warga negara berkaitan dengan hak dan kewajibannya sebagai warga negara. Pengetahuan ini sifatnya mendasar tentang struktur dan sistem politik, pemerintah dan sistem sosial yang ideal sebagaimana terdokumentasi dalam kehidupan berbangsa dan bernegara serta nilai-nilai universal dalam masyarakat demokratis serta cara-cara kerjasama untuk mewujudkan kemajuan bersama dan hidup berdampingan secara damai dalam masyarakat global. Dengan kata lain, pengetahuan kewargaan berisi materi pembelajaran (learning materials), yaitu "sekumpulan pengetahuan, sikap dan keterampilan yang harus dipelajari siswa untuk membantu tercapainya kompetensi atau tujuan pembelajaran" (Gafur, 2012).

Berdasarkan Lampiran Permendiknas No. 22 Tahun 2006 tentang Standar Isi, materi pembelajaran Pendidikan Kewarganegaraan tingkat SMP/MTs 
dikelompokkan ke dalam delapan ruang lingkup materi, yaitu: Persatuan dan Kesatuan bangsa; Norma, hukum dan peraturan; Hak asasi manusia; Kebutuhan warga negara; Konstitusi Negara; Kekuasan dan Politik; Pancasila; dan Globalisasi. Kedelapan ruang lingkup materi PKn SMP/MTs tersebut selanjutnya diperinci ke dalam Standar Kompetensi dan Kompetensi Dasar yang masingmasing berarti sebagai berikut:

Standar Kompetensi adalah kualifikasi kemampuan minimal peserta didik yang menggambarkan penguasaan sikap, pengetahuan, dan keterampilan yang diharapkan dicapai pada setiap tingkat dan/atau semester; standar kompetensi terdiri atas sejumlah kompetensi dasar sebagai acuan baku yang harus dicapai dan berlaku secara nasional. Sedangkan Kompetensi Dasar merupakan sejumlah kemampuan yang harus dimiliki peserta didik dalam mata pelajaran tertentu sebagai rujukan untuk menyusun indikator kompetensi (Permendiknas No. 41 Tahun 2007 tentang Standar Proses untuk Satuan Pendidikan Dasar dan Menengah).

Pengetahuan kewargaan yang termuat dalam Standar Kompetensi dan Kompetensi Dasar atau materi pembelajaran Pendidikan Kewarganegaraan SMP/MTs, menurut Merill (Gafur, 2012) memuat "fakta, konsep, prinsip, dan prosedur yang relevan, dan ditulis dalam bentuk butir-butir sesuai dengan rumusan indikator pencapaian kompetensi”. Muatan jenis pengetahuan kewargaan tersebut digambarkan dalam tabel berikut:

Tabel 1 Jenis Pengetahuan Kewargaan

\begin{tabular}{|c|c|c|}
\hline Materi & Penjelasan & Contoh \\
\hline Fakta & $\begin{array}{l}\text { sifat dari suatu gejala, peristiwa, benda, } \\
\text { yang wujudnya dapat ditangkap oleh } \\
\text { panca indera. }\end{array}$ & $\begin{array}{l}\text { Ibukota Indonesia } \\
\text { adalah Jakarta. Manusia } \\
\text { berjalan dengan kaki. }\end{array}$ \\
\hline Konsep & $\begin{array}{l}\text { abstraksi kesamaan atau keterhubungan } \\
\text { dari sekelompok benda atau sifat. }\end{array}$ & $\begin{array}{l}\text { konsep anak laki-laki, } \\
\text { anak perempuan, pasar, } \\
\text { dll. }\end{array}$ \\
\hline Prosedur & $\begin{array}{l}\text { materi pembelajaran yang berhubungan } \\
\text { dengan kemampuan siswa untuk } \\
\text { menjelaskan langkah-langkah secara } \\
\text { sistematis tentang sesuatu. }\end{array}$ & $\begin{array}{l}\text { langkah-langkah } \\
\text { percobaan. }\end{array}$ \\
\hline Prinsip & $\begin{array}{l}\text { Hubungan antara dua atau lebih konsep } \\
\text { yang sudah teruji secara empiris } \\
\text { dinamakan generalisasi yang selanjutnya } \\
\text { dapat ditarik ke dalam prinsip. }\end{array}$ & $\begin{array}{l}\text { prinsip radiasi, } \\
\text { penguapan, dll. }\end{array}$ \\
\hline
\end{tabular}

Sumber: Diolah dari Gafur (2012)

Berdasarkan analisis terhadap buku teks BMKn (1), (2), dan (3) karya Samidi dan Widyaningtyas, pada dasarnya, materi substansi yang disajikan dalam 
buku teks BMKn sudah mengacu pada Standar Kompetensi dan Kompetensi Dasar Mata Pelajaran Pendidikan Kewarganegaraan yang disusun oleh Badan Standar Nasional Pendidikan (BSNP), sebagaimana ditetapkan melalui Permendiknas No. 22 Tahun 2006 tentang Standar Isi. Dalam proses pengembangan materi substansi pengetahuan kewargaan ke dalam buku teks, setidaknya ada tiga langkah yang diikuti oleh penulis, yaitu:

1. Mengkaji dan menentukan Standar Kompetensi

2. Mengkaji dan menentukan Kompetensi Dasar

3. Mengidentifikasi Materi Pokok/Pembelajaran

Ketiga langkah tersebut tercermin dalam buku teks BMKn (1), (2), dan (3) sebagaimana tergambar dalam tabel berikut:

\section{Tabel 2 Substansi Materi Buku Teks BMKn (1)}

\begin{tabular}{|c|c|c|c|}
\hline Standar Kompetensi & \multicolumn{2}{|r|}{ Kompetensi Dasar } & $\begin{array}{c}\text { Materi Pokok dalam Buku } \\
\text { Teks }\end{array}$ \\
\hline $\begin{array}{l}\text { 1. Menunjukkan sikap } \\
\text { positif terhadap } \\
\text { norma-norma yang } \\
\text { berlaku dalam } \\
\text { kehidupan } \\
\text { bermasyarakat, } \\
\text { berbangsa, dan } \\
\text { bernegara }\end{array}$ & 1.1 & $\begin{array}{l}\text { Mendeskripsikan hakikat } \\
\text { norma-norma, kebiasaan, } \\
\text { adat istiadat, peraturan, } \\
\text { yang berlaku dalam } \\
\text { masyarakat } \\
\text { Menjelaskan hakikat dan } \\
\text { arti penting hukum bagi } \\
\text { warga negara } \\
\text { Menerapkan norma-norma, } \\
\text { kebiasaan, adat istiadat dan } \\
\text { peraturan yang berlaku } \\
\text { dalam kehidupan } \\
\text { bermasyarakat, berbangsa } \\
\text { dan bernegara }\end{array}$ & $\begin{array}{l}\text { BAB I Peraturan, norma, dan } \\
\text { hukum } \\
\text { A. Hakikat norma-norma yang } \\
\text { berlaku dalam masyarakat } \\
\text { B. Hakikat dan arti penting } \\
\text { hukum } \\
\text { C. Penerapan norma-norma } \\
\text { dalam kehidupan } \\
\text { masyarakat, berbangsa, dan } \\
\text { bernegara }\end{array}$ \\
\hline $\begin{array}{ll}\text { 2. } & \text { Mendeskripsikan } \\
\text { makna Proklamasi } \\
\text { Kemerdekaan dan } \\
\text { Konstitusi Pertama }\end{array}$ & 2.2 & $\begin{array}{l}\text { Menjelaskan makna } \\
\text { proklamasi kemerdekaan } \\
\text { Mendeskripsikan suasana } \\
\text { kebatinan konstitusi } \\
\text { pertama } \\
\text { Menganalisis hubungan } \\
\text { antara proklamasi } \\
\text { kemerdekaan dan UUD } \\
1945 \\
\text { Menunjukkan sikap positif } \\
\text { terhadap makna proklamasi } \\
\text { kemerdekaan dan suasana } \\
\text { kebatinan konstitusi } \\
\text { pertama }\end{array}$ & $\begin{array}{l}\text { Bab } 2 \text { Proklamasi dan Konstitusi } \\
\text { Pertama } \\
\text { A. Proklamasi kemerdekaan } \\
\text { B. Suasana kebatinan dan nilai- } \\
\text { nilai konstitusi pertama } \\
\text { C. Sikap positif terhadap makna } \\
\text { proklamasi kemerdekaan dan } \\
\text { nilai-nilai konstitusi pertama }\end{array}$ \\
\hline $\begin{array}{l}\text { 3. } \\
\text { penampilkan sikap } \\
\text { pesitif terhadap } \\
\text { perlindungan dan } \\
\text { penegakan Hak } \\
\text { Asasi Manusia } \\
\text { (HAM) }\end{array}$ & 3.1 & $\begin{array}{l}\text { Menguraikan hakikat, } \\
\text { hukum dan kelembagaan } \\
\text { HAM } \\
\text { Mendeskripsikan kasus } \\
\text { pelanggaran dan upaya } \\
\text { penegakan HAM }\end{array}$ & $\begin{array}{l}\text { Bab } 3 \text { Hak Asasi Manusia } \\
\text { A. Hakikat hak asasi manusia } \\
\text { B. Menganalisis kasus } \\
\text { pelanggaran hak asasi } \\
\text { manusia di Indonesia } \\
\text { C. Menghargai upaya }\end{array}$ \\
\hline
\end{tabular}




\begin{tabular}{|c|c|c|c|}
\hline \multirow[t]{2}{*}{ Standar Kompetensi } & \multicolumn{2}{|r|}{ Kompetensi Dasar } & $\begin{array}{c}\text { Materi Pokok dalam Buku } \\
\text { Teks }\end{array}$ \\
\hline & & $\begin{array}{l}\text { Menghargai upaya } \\
\text { perlindungan HAM } \\
\text { Menghargai upaya } \\
\text { penegakan HAM }\end{array}$ & $\begin{array}{ll} & \text { perlindungan hak asasi } \\
\text { manusia } \\
\text { D. Menghargai upaya } \\
\text { penegakan hak asasi manusia } \\
\text { E. Dukungan masyarakat dalam } \\
\text { upaya penegakan hak asasi } \\
\text { manusia }\end{array}$ \\
\hline $\begin{array}{ll}\text { 4. } & \text { Menampilkan } \\
\text { perilaku } \\
\text { kemerdekaan } \\
\text { mengemukakan } \\
\text { pendapat }\end{array}$ & 4.1 & $\begin{array}{l}\text { Menjelaskan hakikat } \\
\text { kemerdekaan } \\
\text { mengemukakan pendapat } \\
\text { Menguraikan pentingnya } \\
\text { kemerdekaan } \\
\text { mengemukakan pendapat } \\
\text { secara bebas dan } \\
\text { bertanggung jawab } \\
\text { Mengaktualisasikan } \\
\text { kemerdekaan } \\
\text { mengemukakan pendapat } \\
\text { secara bebas dan } \\
\text { bertanggung jawab }\end{array}$ & $\begin{array}{l}\text { Bab IV Kemerdekaan } \\
\text { mengemukakan pendapat } \\
\text { A. Hakikat kemerdekaan } \\
\text { mengemukakan pendapat } \\
\text { B. Arti penting kemerdekaan } \\
\text { mengemukakan pendapat } \\
\text { secara bebas dan } \\
\text { bertanggung jawab } \\
\text { C. Mengaktualisasikan } \\
\text { kemerdekaan } \\
\text { mengemukakan pendapat }\end{array}$ \\
\hline
\end{tabular}

Tabel 3 Substansi Materi Buku Teks BMKn (2)

\begin{tabular}{|c|c|c|c|}
\hline Standar Kompetensi & \multicolumn{2}{|r|}{ Kompetensi Dasar } & $\begin{array}{c}\text { Materi Pokok dalam Buku } \\
\text { Teks }\end{array}$ \\
\hline $\begin{array}{l}\text { 1. Menampilkan } \\
\text { perilaku yang sesuai } \\
\text { dengan nilai-nilai } \\
\text { Pancasila }\end{array}$ & 1.1 & $\begin{array}{l}\text { Menjelaskan Pancasila } \\
\text { sebagai dasar negara dan } \\
\text { ideologi negara } \\
\text { Menguraikan nilai-nilai } \\
\text { Pancasila sebagai dasar } \\
\text { negara dan ideologi negara } \\
\text { Menunjukkan sikap positif } \\
\text { terhadap Pancasila dalam } \\
\text { kehidupan berbangsa dan } \\
\text { bernegara } \\
\text { Menampilkan sikap positif } \\
\text { terhadap Pancasila dalam } \\
\text { kehidupan bermasyarakat }\end{array}$ & $\begin{array}{l}\text { Bab } 1 \text { Ideologi dan nilai-nilai } \\
\text { Pancasila } \\
\text { A. Pancasila sebagai ideologi } \\
\text { dan dasar negara } \\
\text { B. Nilai-nilai Pancasila sebagai } \\
\text { dasar negara dan ideologi } \\
\text { negara } \\
\text { C. Sikap positif terhadap } \\
\text { ideologi Pancasila dalam } \\
\text { kehidupan bermasyarakat, } \\
\text { berbangsa, dan bernegara }\end{array}$ \\
\hline 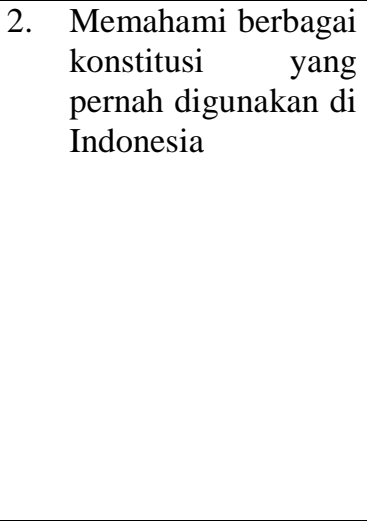 & $\begin{array}{l}2.3 \\
2.4\end{array}$ & $\begin{array}{l}\text { Menjelaskan berbagai } \\
\text { konstitusi yang pernah } \\
\text { berlaku di Indonesia } \\
\text { Menganalisis } \\
\text { penyimpangan- } \\
\text { penyimpangan terhadap } \\
\text { konstitusi yang berlaku di } \\
\text { Indonesia } \\
\text { Menunjukkan hasil-hasil } \\
\text { amandemen UUD 1945 } \\
\text { Menampilkan sikap positif } \\
\text { terhadap pelaksanaan UUD } \\
\text { 1945 hasil amandemen }\end{array}$ & $\begin{array}{l}\text { Bab } 2 \text { Konstitusi negara } \\
\text { A. Konstitusi di Indonesia } \\
\text { B. Sistem ketatanegaraan di } \\
\text { Indonesia berdasarkan } \\
\text { konstitusi yang berlaku dan } \\
\text { bentuk penyimpangannya } \\
\text { C. Arti pentingnya amandemen } \\
\text { UUD } 1945 \\
\text { D. Menampilkan sikap positif } \\
\text { terhadap pelaksanaan UUD } \\
\text { 1945 hasil perubahan }\end{array}$ \\
\hline $\begin{array}{l}\text { 3. } \\
\text { ketaatan terhadap } \\
\text { perundang- }\end{array}$ & 3.1 & $\begin{array}{l}\text { Mengidentifikasi tata } \\
\text { urutan peraturan } \\
\text { perundang-undangan }\end{array}$ & $\begin{array}{l}\text { Bab } 3 \text { Peraturan perundang- } \\
\text { undangan nasional } \\
\text { A. Tata urutan peraturan }\end{array}$ \\
\hline
\end{tabular}




\begin{tabular}{|c|c|c|c|}
\hline Standar Kompetensi & & Kompetensi Dasar & $\begin{array}{c}\text { Materi Pokok dalam Buku } \\
\text { Teks }\end{array}$ \\
\hline undangan nasional & 3.4 & 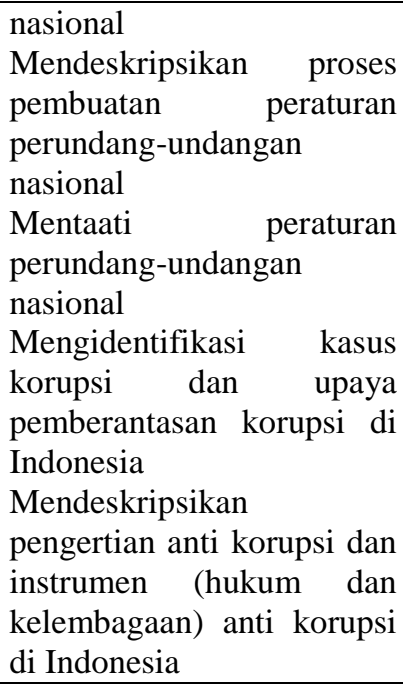 & 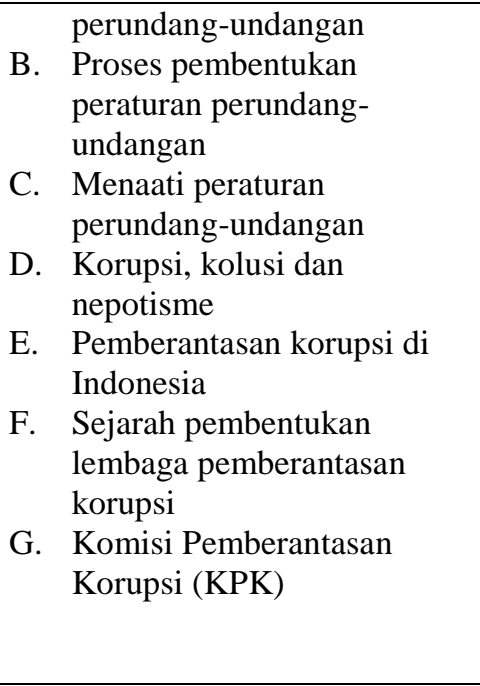 \\
\hline $\begin{array}{ll}\text { 4. } & \text { Memahami } \\
\text { pelaksanaan } & \\
\text { demokrasi } & \text { dalam } \\
\text { berbagai } & \text { aspek } \\
\text { kehidupan } & \end{array}$ & $\begin{array}{l}4.1 \\
4.2\end{array}$ & $\begin{array}{lr}\text { Menjelaskan } & \text { hakikat } \\
\text { demokrasi } & \\
\text { Menjelaskan pentingnya } \\
\text { kehidupan demokratis } \\
\text { dalam bermasyarakat, } \\
\text { berbangsa, dan bernegara } \\
\text { Menunjukkan sikap positif } \\
\text { terhadap pelaksanaan } \\
\text { demokrasi dalam berbagai } \\
\text { kehidupan }\end{array}$ & $\begin{array}{l}\text { Bab } 4 \text { Masyarakat Demokratis } \\
\text { A. Hakikat demokrasi } \\
\text { B. Kehidupan demokrasi dalam } \\
\text { kenegaraan } \\
\text { C. Hakikat demokrasi Pancasila } \\
\text { D. Menunjukkan sikap positif } \\
\text { terhadap pelaksanaan } \\
\text { demokrasi dalam berbagai } \\
\text { kehidupan }\end{array}$ \\
\hline $\begin{array}{ll}\text { 5. } & \text { Memahami } \\
\text { kedaulatan rakyat } & \text { ram } \\
\text { dalam } & \text { sistem } \\
\text { pemerintahan } & \text { di } \\
\text { Indonesia } & \end{array}$ & $\begin{array}{l}5.1 \\
5.2\end{array}$ & $\begin{array}{l}\text { Menjelaskan makna } \\
\text { kedaulatan rakyat } \\
\text { Mendeskripsikan sistem } \\
\text { pemerintahan Indonesia } \\
\text { dan peran lembaga negara } \\
\text { sebagai pelaksana } \\
\text { kedaulatan rakyat } \\
\text { Menunjukkan sikap positif } \\
\text { terhadap kedaulatan rakyat } \\
\text { dan sistem pemerintahan di } \\
\text { Indonesia }\end{array}$ & $\begin{array}{l}\text { Bab } 5 \text { kedaulatan rakyat dalam } \\
\text { sistem pemerintahan di Indonesia } \\
\text { A. Kedaulatan rakyat } \\
\text { B. Pemegang kedaulatan rakyat } \\
\text { C. Hakikat partai politik } \\
\text { D. Menampilkan sikap positif } \\
\text { terhadap kedaulatan rakyat } \\
\text { dan sistem politik Indonesia }\end{array}$ \\
\hline
\end{tabular}

Tabel 4 Susbstansi Materi Buku Teks BMKn (3)

\begin{tabular}{|c|c|c|}
\hline Standar Kompetensi & Kompetensi Dasar & $\begin{array}{c}\text { Materi Pokok dalam Buku } \\
\text { Teks }\end{array}$ \\
\hline $\begin{array}{l}\text { 1. } \text { Menampilkan } \\
\text { partisipasi dalam } \\
\text { usaha pembelaan } \\
\text { negara }\end{array}$ & $\begin{array}{l}\text { 1.1 } \\
\text { Menjelaskan pentingnya } \\
\text { usaha pembelaan negara } \\
\text { 1.2 } \begin{array}{l}\text { Mengidentifikasi bentuk- } \\
\text { bentuk usaha pembelaan } \\
\text { negara }\end{array} \\
\text { 1.3 } \begin{array}{l}\text { Menampilkan peran serta } \\
\text { dalam usaha pembelaan } \\
\text { negara }\end{array} \\
\end{array}$ & $\begin{array}{l}\text { Bab } 1 \text { Usaha Pembelaan Negara } \\
\text { A. Negara } \\
\text { B. Arti pentingnya usaha } \\
\text { pembelaan negara } \\
\text { C. Bentuk-bentuk usaha } \\
\text { pembelaan negara } \\
\text { D. Berperan serta dalam usaha } \\
\text { pembelaan negara } \\
\end{array}$ \\
\hline $\begin{array}{ll}\text { 2. } & \text { Memahami } \\
\text { pelaksanaan } \\
\text { otonomi daerah }\end{array}$ & $\begin{array}{ll}\text { 2.1 } & \begin{array}{l}\text { Mendeskripsikan } \\
\text { otonomi daerah }\end{array} \\
\text { 2.2 } & \begin{array}{l}\text { Menjelaskan } \\
\text { partisipasi masyarakat dalam }\end{array} \\
\end{array}$ & $\begin{array}{l}\text { Bab } 2 \text { Otonomi Daerah } \\
\text { A. Pengertian dan hakikat } \\
\text { otonomi daerah } \\
\text { B. Dasar hukum pelaksanaan }\end{array}$ \\
\hline
\end{tabular}




\begin{tabular}{|c|c|c|}
\hline Standar Kompetensi & Kompetensi Dasar & $\begin{array}{c}\text { Materi Pokok dalam Buku } \\
\text { Teks }\end{array}$ \\
\hline & $\begin{array}{l}\text { perumusan kebijakan publik } \\
\text { di daerah }\end{array}$ & $\begin{array}{ll}\text { C. Tujuan dan manfaat } \\
\text { pelaksanaan otonomi daerah } \\
\text { D. Prinsip dan asa otonomi } \\
\text { daerah } \\
\text { E. Pembagian urusan } \\
\text { pemerintahan } \\
\text { F. Pemerintahan daerah } \\
\text { G. Masalah-masalah dalam } \\
\text { pelaksanaan otonomi daerah } \\
\text { H. Pentingnya partisipasi } \\
\text { masyarakat dalam } \\
\text { I. Perumusan kebijakan public } \\
\text { Partisipasi masyarakat dalam } \\
\text { pelaksanaan otonomi daerah }\end{array}$ \\
\hline $\begin{array}{l}\text { 3. Memahami dampak } \\
\text { globalisasi dalam } \\
\text { kehidupan } \\
\text { bermasyarakat, } \\
\text { berbangsa, dan } \\
\text { bernegara }\end{array}$ & 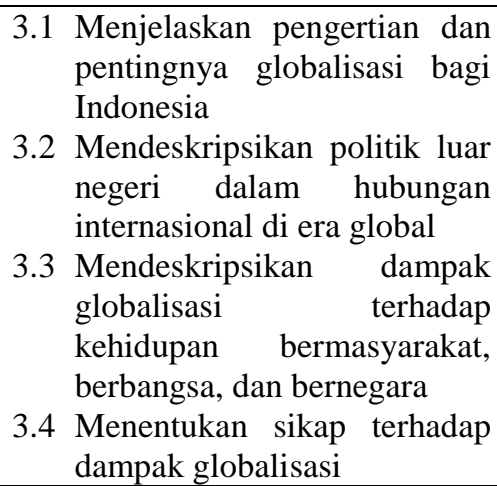 & $\begin{array}{l}\text { Bab } 3 \text { Globalisasi } \\
\text { A. Arti penting globalisasi bagi } \\
\text { Indonesia } \\
\text { B. Politik luar negeri dalam } \\
\text { hubungan internasional di } \\
\text { era globalisasi } \\
\text { C. Dampak globalisasi terhadap } \\
\text { kehidupan bermasyarakat, } \\
\text { berbangsa dan bernegara } \\
\text { D. Menentukan sikap terhadap } \\
\text { dampak globalisasi }\end{array}$ \\
\hline 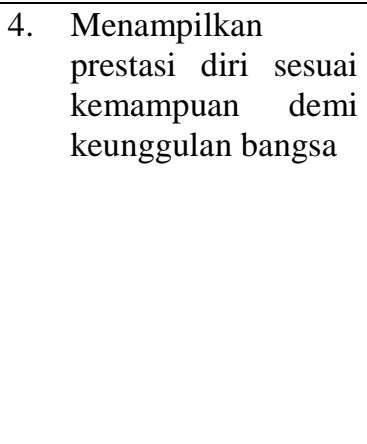 & $\begin{array}{l}\text { 4.1 } \begin{array}{l}\text { Menjelaskan pentingnya } \\
\text { prestasi diri bagi keunggulan } \\
\text { bangsa }\end{array} \\
\text { 4.2 } \begin{array}{l}\text { Mengenal potensi diri untuk } \\
\text { berprestasi } \\
\text { kemampuan } \\
\text { 4.3 } \begin{array}{l}\text { Menampilkan peran serta } \\
\text { dalam berbagai aktivitas }\end{array} \\
\text { untuk mewujudkan prestasi } \\
\text { diri sesuai kemampuan demi } \\
\text { keunggulan bangsa }\end{array}\end{array}$ & $\begin{array}{l}\text { Bab } 4 \text { Prestasi diri demi } \\
\text { keunggulan bangsa } \\
\text { A. Arti penting prestasi diri bagi } \\
\text { keunggulan bangsa } \\
\text { B. Potensi diri untuk berprestasi } \\
\text { C. Berpartisipasi pada berbagai } \\
\text { aktivitas untuk mewujudkan } \\
\text { prestasi diri sesuai dengan } \\
\text { kemampuan demi } \\
\text { keunggulan bangsa }\end{array}$ \\
\hline
\end{tabular}

Untuk pengembangan pengetahuan kewargaan (yang berupa fakta, konsep, prinsip, dan prosedur), selain menyajikan pembahasan materi pokok pada setiap bab, penulis juga memperkaya pengetahuan kewargaan dengan menyajikan box tambahan pada setiap bab, yaitu: pemuatan gambar, biro hukum, info, tokoh, dan kamus kewarganegaraan. Berdasarkan Petunjuk Penggunaan buku, Gambar disajikan agar peserta didik mengetahui gambar yang berkaitan dengan pembelajaran; Biro hukum, disajikan agar peserta didik dapat belajar tentang hukum dan peraturan perundang-undangan melalui materi atau tugas. Info, disajikan agar peserta didik dapat belajar untuk menganalisis informasi atau berita 
dari satu permasalahan yang ada. Tokoh, disajikan agar peserta didik dapat menambah pengetahuan melalui pengenalan tokoh nasional sehingga dapat meningkatkan jiwa nasionalisme. Kamus, disajikan agar peserta didik dapat mengetahui arti setiap kata penting dalam materi.

\section{Pengembangan Kompetensi Keterampilan Kewargaan dalam Buku Teks PKn SMP/MTs}

Dalam bahasan tentang keterampilan kewargaan (civic skill) pada bagian sebelumnya, dapat dipahami bahwa civic skill dikembangkan dari pengetahuan kewargaan, dengan maksud agar pengetahuan yang diperoleh menjadi sesuatu yang bermakna, sebab dapat dimanfaatkan untuk menghadapi masalah-masalah kehidupan berbangsa dan bernegara. Keterampilan kewargaan ini meliputi keterampilan-keterampilan intelektual (intellectual skills) dan keterampilan partisipasi (participation skills).

Pertama, keterampilan intelektual melatih warga negara untuk memiliki kemampuan berpikir kritis (berpengetahuan, efektif, dan bertanggung jawab). Dengan menggunakan deskripsi The National Standards of Civic and Government dan The Civic Framework for 1998 National Assessment of Educational Progress (NAEPP), kategori keterampilan-keterampilan ini meliputi: 1) identifying and describing (mengidentifikasi dan mendeskripsikan); 2) explaining and analyzing; (menjelaskan dan menganalisis), and 3) evaluating, taking and defending positions on public issues (mengevaluasi, menarik dan mempertahankan posisi) dalam isu-isu publik (Branson, 1998:8).

Dalam buku teks BMKn (1), (2), dan (3), keterampilan kewargaan (yang meliputi keterampilan intelektual, dan keterampilan partisipatif) ini dikembangkan, baik dalam bentuk Materi yang berkaitan dengan keterampilan kewargaan, maupun dalam latihan-latihan berupa box Uji Psikomotorik. Bahkan, pada beberapa bagian dapat pula ditemui dalam bentuk Uji Kognitif dan Uji Afektif yang substansinya sebenarnya lebih tepat disebut sebagai uji Psikomotorik. Dalam petunjuk penggunaan buku, Uji Psikomotorik disajikan agar peserta didik dapat belajar berpendapat terhadap suatu masalah yang berkaitan dengan materi sehingga dapat menambah kompetensi. 
Secara garis besar, sajian materi, dan latihan-latihan (uji psikomotorik) yang terdapat dalam buku teks BMKn (1), (2), (3), belum secara tegas menyebut keterampilan intelektual yang sejatinya dimiliki warga negara. Padahal keterampilan-keterampilan intelektual ini penting untuk seorang warga negara agar ia memiliki kemampuan berpikir kritis.

Kedua, tentang keterampilan partisipatif (meliputi interacting, monitoring, and influencing, Branson [1998:9]) yang dikembangkan melalui Buku teks BMKn (1), (2), dan (3), dapat dikemukakan hasil penelitian sebagai berikut:

a. Interaksi (interacting), berkaitan dengan keterampilan-keterampilan warga negara dalam berkomunikasi dan bekerja sama dengan orang lain. Berinteraksi adalah menjadi tanggap terhadap warga negara yang lain. Interaksi berarti bertanya, menjawab, dan berunding dengan santun, demikian juga membangun koalisi-koalisi dan mengelola konflik dengan cara yang damai dan jujur. Untuk mengembangkan kemampuan interaksi ini, penulis merancang kegiatan siswa untuk berinteraksi dengan warga negara yang lain melalui uji kognitif, sebagai contoh dalam buku teks BMKn (1) terdapat uji kognitif sebagai berikut:

\section{Uji Kognitif}

Lakukan wawancara terhadap masyarakat di sekitar kalian.

1. Pilihlah beberapa orang yang memiliki keyakinan atau agama yang berbedabeda.

2. Tanyakan kepada mereka tentang bentuk norma agama menurut keyakinannya.

3. Tuliskan penjelasan tentang bentuk-bentuk norma agama tersebut (BMKn [1], hlm 4)

Judul box Uji Kognitif di atas, jika dilihat substansinya ternyata tidak tepat. Sebab substansinya lebih menuntun siswa untuk melakukan sesuatu, yaitu berinteraksi melalui wawancara. Semestinya, judul box yang tepat adalah Uji Psikomotorik.

b. Memonitor (monitoring) sistem politik dan pemerintahan, mengisyaratkan pada kemampuan yang dibutuhkan warga negara untuk terlibat dalam proses politik dan pemerintahan. Monitoring juga berarti fungsi pengawasan atau watchdog warga negara. Kegiatan monitoring ini, walaupun tidak secara 
eksplisit disebutkan sebagai kegiatan monitoring, dapat ditemui dalam uji psikomotorik seperti contoh berikut:

\section{Uji Psikomotorik}

Bentuklah kelompok dalam kelas kalian. Lakukan kegiatan berikut.

1. Amatilah jalan, perempatan, pertigaan di sekitar kalian

2. Tuliskan banyaknya pelanggaran yang terjadi

3. Jelaskan penyebab terjadinya pelanggaran itu.

4. Menurut kalian, usaha apa untuk mengatasi tidak terjadinya pelanggaran itu. Hasil kegiatan ditulis dalam bentuk laporan tertulis.

(BMKn [1], hlm 22)

c. Mempengaruhi (Influencing), mengisyaratkan pada kemampuan proses-proses politik dan pemerintahan dalam masyarakat.

Keterampilan partisipatoris dalam hal mempengaruhi yang penulis rancang terdapat dalam contoh berikut ini:

\section{Uji Afektif}

Tujuan negara yang tercantum dalam Pembukaan UUD 1945 Alinea IV menyatakan bahwa negara melindungi segenap bangsa Indonesia dan seluruh tumpah darah Indonesia.

1. Menurut pendapat kalian, bagaimana upaya pelaksanaan tujuan tersebut?

2. Bagaimana peran serta kalian (cetak tebal oleh peneliti) dalam pelaksanaan tujuan tersebut?

(BMKn [1], hlm 47)

Dari box Uji Afektif tersebut, keterampilan partisipatoris yang hendak dikembangkan oleh penulis terdapat pada kata yang dicetak tebal dalam pertanyaan kedua, yaitu tentang peran serta siswa dalam pelaksanaan tujuan negara. Hal ini sama seperti yang ditemui pada Uji Afektif dalam BMKn (1) lainnya seperti dikemukakan berikut:

\section{Uji Afektif}

Dewasa ini kita sering mendengar peristiwa penganiayaan, penyiksaan, ataupun penderitaan lainnya yang dialami para TKW di luar negeri. Bagaimanakah usaha dan peranan pemerintah Indonesia, khususnya Departemen Hukum dan HAM untuk mengatasi peristiwa tersebut? Bagaimana pula peran serta (cetak tebal oleh peneliti) yang dapat kalian lakukan ketika mendengar ada tetangga kalian ingin ikut menjadi TKW?

(BMKn [1], hlm 89)

Kata yang dicetak tebal menunjukkan pertanyaan yang menuntut partisipasi siswa dalam permasalahan penderitaan para TKW di luar negeri. Siswa 
diminta memikirkan peran serta yang dapat mereka lakukan ketika mendengar ada tetangganya yang berkeinginan menjadi TKW di luar negeri.

\section{Pengembangan Kompetensi Watak Kewargaan dalam Buku Teks PKn SMP/MTs}

Watak kewargaan (civic disposition) dimaksud oleh Quigley, dkk (1991:11) adalah "...those attitudes and habit of mind of the citizen that are conducive to the healthy functioning and common good of the democratic system" yaitu sikap dan kebiasaan berpikir warga negara yang menopang berkembangnya fungsi sosial yang sehat dan jaminan kepentingan umum dari sistem demokrasi. Secara konseptual, menurut Quigley, dkk (1991:13-14) watak kewargaan (civic disposition) mencakup sejumlah karakteristik kepribadian, yakni:

civility (respect and civil discourse), individual responsibility, selfdiscipline, civic-mindedness, open-mindedness (openness, skepticism, recognition of ambiguity), compromise (conflict of principles and limit to compromise), toleration of diversity, patience and persistence, compassion, generosity, and loyalty to the nation and its principles.

Berdasarkan kutipan di atas, diketahui beberapa karakteristik kepribadian yang membangun watak kewargaan sebagai berikut: 1) kesopanan, yang mencakup penghormatan dan interaksi manusiawi; 2) tanggung jawab individual; 3) disiplin diri; 4) kepedulian terhadap masyarakat; 5) keterbukaan pikiran, yang mencakup keterbukaan, skeptisisme, pengenalan terhadap kemenduaan; 6) sikap kompromi, yang mencakup prinsip-prinsip konflik dan batas-batas kompromi; 7) toleransi pada keragaman; 8) kesabaran dan keajekan; 9) keharuan; 10) kemurahan hati; dan 11) kesetiaan terhadap bangsa dan segala prinsipnya.

Untuk keperluan pengembangan watak kewargaan, buku teks BMKn (1), (2), dan (3) telah menambahkan box khusus dalam setiap bab untuk mengungkap nilai-nilai watak atau karakter yang semestinya dikembangkan oleh siswa, yaitu box Nilai Karakter Bangsa. Di samping itu, terdapat pula box Nilai Budi Pekerti pada setiap akhir bab, dan bahkan muncul box Nilai Pendidikan Kewirausahaan (ditemui pada BMKn [1], hlm 81).

Dari tiga tingkatan buku teks BMKn, karakter bangsa yang diungkap dan dikembangkan oleh penulis, yaitu dalam box karakter bangsa sebagai berikut: 
Tabel 5 Nilai Karakter Bangsa pada Buku Teks BMKn (1), (2), dan (3)

SMP/MTs

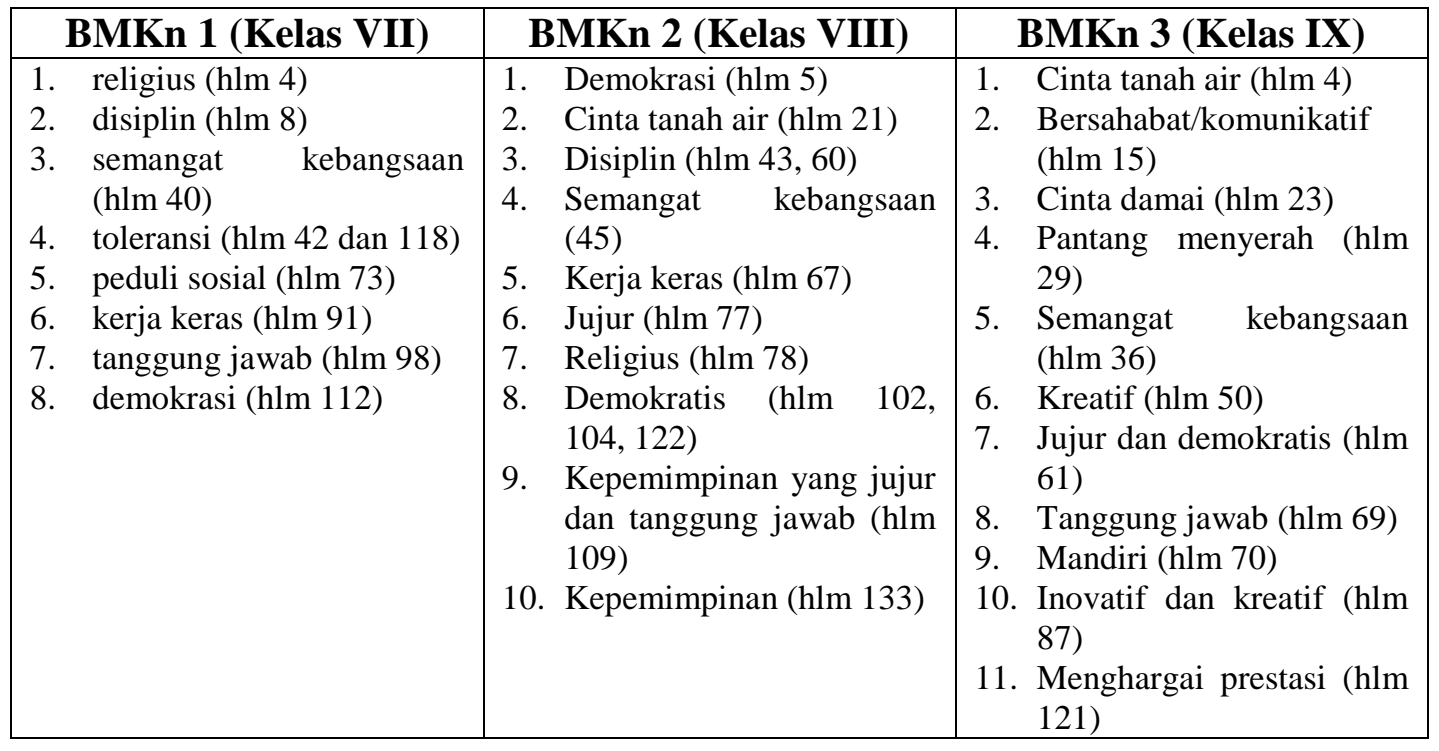

Sementara itu, nilai budi pekerti pada buku teks BMKn (1) diuraikan dalam tabel berikut:

Tabel 6 Nilai Budi Pekerti pada Buku teks BMKn (1)

\begin{tabular}{|c|c|c|c|}
\hline $\begin{array}{c}\text { Bab 1 } \\
\text { Peraturan, norma, } \\
\text { dan hukum }\end{array}$ & $\begin{array}{c}\text { Bab 2 } \\
\text { Proklamasi dan } \\
\text { Konstitusi Pertama }\end{array}$ & $\begin{array}{c}\text { Bab 3 } \\
\text { Hak Asasi Manusia }\end{array}$ & $\begin{array}{c}\text { Bab 4 } \\
\text { Kemerdekaan } \\
\text { Mengemukakan } \\
\text { Pendapat }\end{array}$ \\
\hline $\begin{array}{l}\text { Nilai Kereligiusan } \\
\text { - } \quad \text { Mengembangkan } \\
\text { sikap toleransi } \\
\text { Melaksanakan } \\
\text { ibadah dengan } \\
\text { baik } \\
\text { - Menghormati } \\
\text { orang yang sedang } \\
\text { beribadah } \\
\text { Menolak setiap } \\
\text { sikap, tindakan } \\
\text { dan kebijakan } \\
\text { yang menyimpang } \\
\text { atau menodai } \\
\text { agama } \\
\text { Nilai kepatuhan pada } \\
\text { aturan sosial } \\
\text { Mematuhi tata } \\
\text { tertib sekolah } \\
\text { Mematuhi norma } \\
\text { kesusilaan, } \\
\text { kesopanan dan } \\
\text { peraturan yang } \\
\text { berlaku }\end{array}$ & $\begin{array}{l}\text { Nasionalisme } \\
\text { Memiliki rasa } \\
\text { cinta tanah air } \\
\text { (menghormati } \\
\text { pahlawan, } \\
\text { melakukan } \\
\text { upacara bendera, } \\
\text { memperingati } \\
\text { hari-hari besar } \\
\text { nasional, } \\
\text { menyanyikan } \\
\text { lagu kebangsaan, } \\
\text { melakukan } \\
\text { kegiatan } \\
\text { pelestarian } \\
\text { lingkungan) } \\
\text { Mengutamakan } \\
\text { persatuan dan } \\
\text { kesatuan, } \\
\text { kepentingan } \\
\text { bangsa dan } \\
\text { negara } \\
\text { Memelihara dan } \\
\text { mengembangkan } \\
\text { pilar-pilar }\end{array}$ & $\begin{array}{l}\text { Kejujuran } \\
\text { - } \quad \text { Menepati janji } \\
\text { Berkata dan } \\
\text { bertindak secara } \\
\text { benar sesuai } \\
\text { dengan fakta/tidak } \\
\text { berbohong } \\
\text { Kereligiusan } \\
\text { - } \quad \text { Mengembangkan } \\
\text { toleransi beragama } \\
\text { - Menghormati } \\
\text { orang yang sedang } \\
\text { melaksanakan } \\
\text { ibadah } \\
\text { Kepatuhan pada } \\
\text { aturan sosial } \\
\text { Mematuhi norma, } \\
\text { kebiasaan, adat, } \\
\text { dan peraturan yang } \\
\text { berlaku } \\
\text { Tidak berbuat } \\
\text { sewenang-wenang, } \\
\text { anarkis, main } \\
\text { hakim sendiri } \\
\text { Kesadaran akan hak }\end{array}$ & $\begin{array}{l}\text { Kejujuran } \\
\text { - } \quad \text { Berkata dan } \\
\text { bertindak secara } \\
\text { benar sesuai } \\
\text { dengan } \\
\text { fakta/tidak } \\
\text { berbohong } \\
\text { Demokratis } \\
\text { - Menghormati } \\
\text { pendapat dan } \\
\text { hak orang lain } \\
\text { Tidak } \\
\text { memaksakan } \\
\text { kehendak } \\
\text { kepada orang } \\
\text { lain } \\
\text { Bertanggung jawab } \\
\text { Berani } \\
\text { menanggung } \\
\text { resiko atau } \\
\text { akibat dari } \\
\text { segala } \\
\text { perbuatannya } \\
\text { (BMKn [1], hlm } \\
\text { 122) }\end{array}$ \\
\hline
\end{tabular}




\begin{tabular}{|c|c|c|}
\hline $\begin{array}{l}\text { Tidak berbuat } \\
\text { sewenang-wenang, } \\
\text { anarkis, main } \\
\text { hakim sendiri atau } \\
\text { melakukan } \\
\text { tindakan di luar } \\
\text { ketentuan } \\
\text { Kejujuran } \\
\text { Berkata jujur, } \\
\text { tidak berbohong } \\
\text { (BMKn [1], hlm 22) }\end{array}$ & $\begin{array}{l}\text { kenegaraan, yaitu } \\
\text { Pancasila, UUD } \\
\text { 1945, NKR, dan } \\
\text { Bhineka Tunggal } \\
\text { Ika } \\
\text { Berpikir logis, kritis, } \\
\text { kreatif, dan inovatif } \\
\text { - Memberikan } \\
\text { masukan yang } \\
\text { bersifat } \\
\text { membangun } \\
\text { Memberikan idea } \\
\text { tau gagasan yang } \\
\text { baik untuk } \\
\text { kepentingan } \\
\text { umum } \\
\text { Memaparkan } \\
\text { pendapat } \\
\text { didasarkan pada } \\
\text { fakta empiric } \\
\text { (BMKn [1], hlm 53) }\end{array}$ & $\begin{array}{l}\text { dan kewajiban diri } \\
\text { dan orang lain } \\
\text { - } \quad \text { Bersikap dan } \\
\text { bertindak adil } \\
\text { - } \quad \text { Menghargai hak- } \\
\text { hak orang lain } \\
\text { (BMKn [1], hlm 101). }\end{array}$ \\
\hline
\end{tabular}

Nilai budi pekerti pada buku teks BMKn (2) diuraikan dalam tabel berikut

Tabel 7 Nilai Budi Pekerti pada Buku teks BMKn (2)

\begin{tabular}{|c|c|c|c|c|}
\hline $\begin{array}{l}\text { Bab } 1 \text { Ideologi } \\
\text { dan Nilai-nilai } \\
\text { Pancasila }\end{array}$ & $\begin{array}{c}\text { Bab } 2 \text { Konstitusi } \\
\text { Negara }\end{array}$ & $\begin{array}{l}\text { Bab } 3 \text { Peraturan } \\
\text { Perundang- } \\
\text { undangan } \\
\text { Nasional }\end{array}$ & $\begin{array}{c}\text { Bab 4 } \\
\text { Masyarakat } \\
\text { Demokratis }\end{array}$ & $\begin{array}{c}\text { Bab 5 } \\
\text { Kedaulatan } \\
\text { Rakyat dalam } \\
\text { Sistem } \\
\text { Pemerintahan } \\
\text { Indonesia } \\
\end{array}$ \\
\hline $\begin{array}{l}\text { Nasionalisme } \\
\text { Mengutamaka } \\
\text { n persatuan } \\
\text { dan kesatuan, } \\
\text { kepentingan } \\
\text { bangsa dan } \\
\text { negara } \\
\text { - Melestarikan } \\
\text { dan } \\
\text { mengembangk } \\
\text { an nilai-nilai } \\
\text { dan budaya } \\
\text { daerah } \\
\text { maupun } \\
\text { nasional } \\
\text { Memelihara } \\
\text { dan } \\
\text { mengembangk } \\
\text { an pilar-pilar } \\
\text { kenegaraan, } \\
\text { yaitu } \\
\text { Pancasila, } \\
\text { UUD 1945, }\end{array}$ & $\begin{array}{l}\text { Nasionalisme } \\
\text { Memelihara } \\
\text { dan } \\
\text { mengembangk } \\
\text { an pilar-pilar } \\
\text { kenegaraan, } \\
\text { yaitu } \\
\text { Pancasila, } \\
\text { UUD 1945, } \\
\text { NKRI dan } \\
\text { Bhinneka } \\
\text { Tunggal Ika } \\
\text { Kesadaran akan } \\
\text { hak dan } \\
\text { kewajiban diri } \\
\text { dan orang lain } \\
\text { - Sikap tahu dan } \\
\text { mengerti serta } \\
\text { melaksanakan } \\
\text { apa yang } \\
\text { menjadi } \\
\text { milik/hak diri } \\
\text { sendiri dan }\end{array}$ & $\begin{array}{l}\text { Kesadaran akan } \\
\text { hak dan } \\
\text { kewajiban diri } \\
\text { dan orang lain } \\
\text { - } \quad \text { Sikap tahu dan } \\
\text { mengerti serta } \\
\text { melaksanakan } \\
\text { apa yang } \\
\text { menjadi } \\
\text { milik/hak diri } \\
\text { sendiri dan } \\
\text { orang lain } \\
\text { serta } \\
\text { tugas/kewajiba } \\
\text { n diri sendiri } \\
\text { serta orang } \\
\text { lain } \\
\text { Berpikir logis, } \\
\text { kritis, kreatif, dan } \\
\text { inovatif } \\
\text { Mengemukaka } \\
\text { n / } \\
\text { mengusulkan }\end{array}$ & $\begin{array}{l}\text { Tidak } \\
\text { dikembangk } \\
\text { an nilai-nilai } \\
\text { budi pekerti }\end{array}$ & $\begin{array}{ll}\text { Kejujuran } \\
\text { - } & \text { Berkata } \\
\text { dan } \\
\text { bertindak } \\
\text { secara } \\
\text { benar } \\
\text { sesuai } \\
\text { dengan } \\
\text { fakta/tidak } \\
\text { berbohong } \\
\text { Demokratis } \\
\text { - Menghorm } \\
\text { ati } \\
\text { pendapat } \\
\text { dan hak } \\
\text { orang lain } \\
\text { Tidak } \\
\text { memaksaka } \\
\text { n kehendak } \\
\text { kepada } \\
\text { orang lain } \\
\text { Bertanggun } \\
\text { g jawab: }\end{array}$ \\
\hline
\end{tabular}




\begin{tabular}{|c|c|c|c|c|}
\hline $\begin{array}{l}\text { Bab } 1 \text { Ideologi } \\
\text { dan Nilai-nilai } \\
\text { Pancasila }\end{array}$ & $\begin{array}{c}\text { Bab } 2 \text { Konstitusi } \\
\text { Negara }\end{array}$ & $\begin{array}{c}\text { Bab } 3 \text { Peraturan } \\
\text { Perundang- } \\
\text { undangan } \\
\text { Nasional }\end{array}$ & $\begin{array}{c}\text { Bab 4 } \\
\text { Masyarakat } \\
\text { Demokratis }\end{array}$ & $\begin{array}{c}\text { Bab 5 } \\
\text { Kedaulatan } \\
\text { Rakyat dalam } \\
\text { Sistem } \\
\text { Pemerintahan } \\
\text { Indonesia }\end{array}$ \\
\hline \begin{tabular}{l}
\multicolumn{1}{c}{ NKRI dan } \\
Bhineka \\
Tunggal Ika \\
Berpikir logis, \\
kritis, kreatif, dan \\
inovatif \\
- $\quad$ Mengemukaka \\
n / \\
mengusulkan \\
sesuatu yang \\
masuk akal \\
dengan \\
menggunakan \\
akal yang \\
sehat dan hati \\
nurani yang \\
luhur \\
Memberikan \\
ide atau \\
gagasan yang \\
baik untuk \\
kepentingan \\
umum \\
(BMKn [2], hlm \\
24)
\end{tabular} & $\begin{array}{l}\text { orang lain } \\
\text { serta } \\
\text { tugas/kewajiba } \\
\text { n diri sendiri } \\
\text { serta orang } \\
\text { lain } \\
\text { Berpikir logis, } \\
\text { kritis, kreatif, dan } \\
\text { inovatif } \\
\text { - Mengemukaka } \\
\text { n / } \\
\text { mengusulkan } \\
\text { sesuatu yang } \\
\text { masuk akal } \\
\text { dengan } \\
\text { menggunakan } \\
\text { akal yang } \\
\text { sehat dan hati } \\
\text { nurani yang } \\
\text { luhur } \\
\text { Memberikan } \\
\text { ide atau } \\
\text { gagasan yang } \\
\text { baik untuk } \\
\text { kepentingan } \\
\text { umum } \\
\text { (BMKn [2], hlm } \\
\text { 52) }\end{array}$ & $\begin{array}{l}\text { sesuatu yang } \\
\text { masuk akal } \\
\text { dengan } \\
\text { menggunakan } \\
\text { akal yang } \\
\text { sehat dan hati } \\
\text { nurani yang } \\
\text { luhur } \\
\text { Memberikan } \\
\text { ide atau } \\
\text { gagasan yang } \\
\text { baik untuk } \\
\text { kepentingan } \\
\text { umum } \\
\text { (BMKn [2], hlm } \\
\text { 85) }\end{array}$ & & $\begin{array}{l}\text { berani } \\
\text { menanggun } \\
\text { g resiko } \\
\text { atau akibat } \\
\text { dari segala } \\
\text { perbuatann } \\
\text { ya } \\
\text { (BMKn [2], } \\
\text { hlm 151) }\end{array}$ \\
\hline
\end{tabular}

Nilai budi pekerti pada buku teks BMKn (3) diuraikan dalam tabel berikut:

Tabel 8 Nilai Budi Pekerti pada Buku teks BMKn (3)

\begin{tabular}{|c|c|c|c|}
\hline $\begin{array}{c}\text { Bab 1 } \\
\text { Usaha Pembelaan } \\
\text { Negara }\end{array}$ & $\begin{array}{c}\text { Bab 2 } \\
\text { Otonomi Daerah }\end{array}$ & $\begin{array}{c}\text { Bab 3 } \\
\text { Globalisasi }\end{array}$ & $\begin{array}{c}\text { Bab 4 } \\
\text { Prestasi Diri demi } \\
\text { Keunggulan Bangsa }\end{array}$ \\
\hline $\begin{array}{ll}\text { - } & \text { Cinta tanah air } \\
\text { - } & \text { Nasionalisme } \\
\text { - } & \text { Semangat } \\
& \text { kebangsaan, rasa } \\
& \text { ingin tahu, disiplin } \\
\text { (BMKn [3], hlm 36) }\end{array}$ & $\begin{array}{ll} & \text { Semangat } \\
& \text { kebangsaan } \\
- & \text { peduli } \\
& \text { lingkungan } \\
\text { - } & \text { Bersahabat } \\
\text { - } & \text { Senang membaca } \\
\text { - } & \text { Kreatif } \\
\text { (BMKn [3], hlm 72) } \\
\end{array}$ & $\begin{array}{ll} & \text { Cinta tanah air } \\
\text { - } & \text { Senang } \\
& \text { membaca } \\
\text { - } & \text { Semangat } \\
& \text { kebangsaan } \\
\text { - } & \text { Kerja keras } \\
\text { - } & \text { Rasa ingin tahu } \\
\text { (BMKn [3], hlm 104) }\end{array}$ & $\begin{array}{ll}\text { - } & \text { Senang membaca } \\
\text { - } & \text { Menghargai } \\
& \text { prestasi } \\
\text { - } & \text { Disiplin } \\
\text { - } & \text { Kerja keras } \\
\text { - } & \text { Rasa ingin tahu } \\
\text { (BMKn [3], hlm 124) }\end{array}$ \\
\hline
\end{tabular}

Sementara itu, nilai pendidikan kewirausahaan yang penulis ungkap dalam bukunya adalah nilai komitmen, sebagaimana penjelasan berikut: 


\begin{abstract}
Komitmen
Permasalahan hak asasi manusia ternyata tidak hanya menjadi permasalahan di Indonesia. Penghormatan dan penegakan HAM pun telah mendapat pengakuan dari dunia internasional. Bangsa Indonesia sebagai bagian dari dunia internasional wajib dan turut serta dalam penegakan HAM. Dunia internasional memang telah berkomitmen kuat untuk menegakkan HAM di seantero dunia. Oleh karena itu, sebagai bagian dari dunia ini maka Indonesia pun berkomitmen kuat untuk menegakkan HAM dan menyelesaikan persoalan HAM dengan baik dan benar. (BMKn [1], hlm 81)
\end{abstract}

Box tambahan nilai pendidikan kewirausahaan pada BMKn (1) ini, walaupun pemberian judulnya tidak tepat, tetapi substansi isinya berkaitan dengan pengembangan watak/karakter kewargaan siswa.

Watak kewargaan yang dikembangkan dalam buku teks BMKn (1), (2), dan (3) pada dasarnya ditujukan untuk pengembangan karakter siswa baik sebagai individu, maupun sebagai bagian dari warga negara. Hal ini sejalan dengan pendapat Branson (1998:23) yang menegaskan bahwa civic disposition mengisyaratkan pada karakter publik maupun privat yang penting bagi pemeliharaan dan pengembangan demokrasi konstitusional.

Seperti halnya kompetensi keterampilan kewargaan, watak kewargaan berkembang secara perlahan sebagai akibat dari apa yang telah dipelajari dan dialami oleh seseorang di rumah, sekolah, komunitas, dan organisasi-organisasi civil society (masyarakat kewargaan). Pengalaman-pengalaman demikian menunjukkan bahwa demokrasi mensyaratkan adanya pemerintahan mandiri yang bertanggung jawab dari tiap individu. Karakter privat, seperti bertanggung jawab moral, disiplin diri dan penghargaan terhadap harkat dan martabat manusia dari setiap individu adalah wajib, dan karakter publik, seperti kepedulian sebagai warga negara, kesopanan, mengindahkan aturan main (rule of law), berfikir kritis, dan kemauan untuk mendengar, bernegosiasi dan berkompromi merupakan karakter yang sangat diperlukan agar demokrasi berjalan sukses.

\title{
KESIMPULAN
}

Secara taxonomic, buku teks PKn tingkat SMP/MTs yang diteliti memuat upaya pengembangan komponen kompetensi kewargaan sebagaimana peran dan fungsi Mata Pelajaran PKn. Namun demikian, pengembangan komponen 
kompetensi kewargaan itu sebagian besar masih berorientasi pada penguatan komponen pengetahuan kewargaan.

Dilihat dari tiap-tiap komponen kompetensi kewargaan, penelitian ini menyimpulkan bahwa untuk pengembangan kompetensi pengetahuan kewargaan, penulis telah menyajikan dan mengembangkan materi pembelajaran sesuai dengan tuntutan Standar Isi mata pelajaran Pendidikan Kewarganegaraan, melengkapinya dengan gambar, dan menambahkannya dengan box biro hukum, info, tokoh, dan kamus kewarganegaraan.

Untuk pengembangan kompetensi keterampilan kewargaan, penulis menyajikan materi-materi yang berkaitan dengan keterampilan kewargaan dan menambahkan box uji psikomotorik, atau bahkan uji kognitif dan uji afektif yang substansinya adalah uji psikomotorik. Sekalipun sudah diberi box tambahan berupa uji psikomotorik, tetapi tampak bahwa upaya pengembangan komponen itu belum secara tegas menunjukkan keterampilan intelektual yang memotivasi, merangsang, dan melatih kemampuan berpikir siswa kadar tinggi, dan keterampilan partisipatif yang menuntut partisipasi siswa dalam kehidupan bermasyarakat, berbangsa, dan bernegara.

Sedangkan dalam pengembangan kompetensi watak kewargaan, penulis baru mengupayakannya melalui penyajian box nilai-nilai karakter bangsa dan nilai-nilai budi pekerti yang sifatnya pengetahuan konseptual semata, sekalipun bersumber dan sejalan dengan nilai-nilai karakter bangsa yang dikembangkan oleh Pemerintah.

\section{DAFTAR PUSTAKA}

Abdulkarim, Aim. (2006). Analisis Isi Buku Teks dan Implikasinya dalam Pengembangan Bahan Ajar yang Dapat Memberdayakan Keterampilan Berpikir Siswa. Disertasi SPs UPI: Tidak diterbitkan.

Abdulkarim, Aim. (2010). Mengokohkan Pembelajaran Pendidikan Kewarganegaraan: Sinergi Buku Ajar dan Budaya Belajar. Pidato Pengukuhan Jabatan Guru Besar Tetap dalam Bidang Pembelajaran Pendidikan Kewarganegaraan pada Fakultas Pendidikan Ilmu Pengetahuan Sosial Universitas Pendidikan Indonesia. Bandung: Universitas Pendidikan Indonesia.

Arif, Dikdik Baehaqi. (2008). Pengembangan Warga Negara Multikultural Implikasinya terhadap Kompetensi Kewarganegaraan. Tesis SPs UPI: Tidak diterbitkan. 
Arikunto, Suharsimi. (2002). Prosedur Penelitian Suatu Pendekatan Praktek. Jakarta: PT Rineka Cipta.

Bogdan, R.C dan Biklen, S.K. (1990). Riset Kualitatif untuk Pendidikan: Pengantar ke Teori dan Metode. Terjemahan oleh Munandir dari judul Qualitative Research for Education: An introduction to Theory and Methods. Jakarta: PAU PPAI Universitas Terbuka.

Branson, M.S. (1998). The Role of Civic Education. Calabasas: Center for Civic Education.

Center for Civic Education. (1994). National Standard for Civics and Government. Calabasas, California: Center for Civic Education.

Cogan, John. J. (1999). Developing the Civic Society: The Role of Civic Education. Bandung: CICED.

Cresswell, J.W. (1998). Qualitative Inquiry and Research Design: Choosing Among Five Traditions. London: SAGE Publication.

Gafur, Abdul. (2012). Desain Pembelajaran: Konsep, Model, dan Aplikasinya dalam Perencanaan Pelaksanaan Pembelajaran. Yogyakarta: Penerbit Ombak.

Kerr, David. (1999). Citizenship Education: an International Comparison. London: National Foundation for Educational Research-NFER.

Ketetapan MPR RI No. II/MPR/1978 tentang Pedoman Penghayatan dan Pengamalan Pancasila.

Ketetapan MPR RI No. II/MPR/1998 tentang Garis Garis Besar Haluan Negara.

Miles, M.B. dan Huberman, A. M. (1992). Analisis Data Kualitatif: Buku Sumber tentang Metode-metode Baru. Terjemahan oleh Tjetjep Rohendi Rohidi dari judul Qualitative Data Anlysis. Jakarta: Universitas Indonesia Press.

Moleong, Lexy J. (2002). Metodologi Penelitian Kualitatif. Bandung: PT Remaja Rosdakarya.

Patrick, J.J dan Vontz, T.S. "Components of Education for Democratic Citizenship in the Preparation of Social Studies Teachers", dalam John J. Patrick dan Robert S. Learning, Principles and Practices of Democracy in the Education of Social Studies Teachers, Vol. 1, Bloomington, IN:ERIC Clearinghouse for Social Studies/Social Science Education, ERIC Clearinghouse for International Civic Education, and Civitas, 2001, pp. 3964.

Patrick, John J. (1999). "Education for Constructive Engagement of Citizenship in Democratic Civil Society and Government" dalam Charles F. Bahmueller dan John J. Patrick, Principles and Practices of Education for Democratic Citizenship: International Perspectives and Project. Bloomington, IN: ERIC Clearinghouse for Sosial Studies/Social Science Education and the ERIC Adjunct Clearinghouse for International Civic Education in association with Civitas, 1999. Pp. 41-60). 
Peraturan Menteri Pendidikan Nasional Republik Indonesia Nomor 22 Tahun 2006 tentang Standar Isi.

Peraturan Menteri Pendidikan Nasional Republik Indonesia Nomor 41 Tahun 2007 tentang Standar Proses untuk Satuan Pendidikan Dasar dan Menengah

Pusat Kurikulum Kementerian Pendidikan Nasional. (2010). Pengembangan Pendidikan Budaya dan Karakter Bangsa: Bahan Pelatihan Penguatan Metodologi Pembelajaran Berdasarkan Nilai-nilai Budaya untuk Membentuk Daya Saing dan Karakter Bangsa. Jakarta: Kementerian Pendidikan Nasional.

Quigley, C.N., Buchanan, Jr. J. H., Bahmueller, C.F. (1991). Civitas: A Frame Work for Civic Education. Calabasas: Center for Civic Education.

Sapriya. (2007). Perspektif Pemikiran Pakar Tentang Pendidikan Kewarganegaraan dalam Pembangunan Karakter Bangsa (Sebuah Kajian Konseptual-Filosofis PKn dalam Konteks Pendidikan IPS). Disertasi SPs UPI: tidak diterbitkan.

Somantri, M. Nu'man. (2001). Menggagas Pembaharuan Pendidikan IPS. Bandung: Kerjasama PT Remaja Rosdakarya dengan FPIPS dan PPs Universitas Pendidikan Indonesia.

Torney-Purta, J., Lehmann, R., Oswald, H. dan Schulz, W. (2001). Citizenship and Education in Twenty-Eight Countries: Civic Knowledge and Engagement at Age Fourteen. Amsterdam: The International Association for The Evaluation of Educational Achievement.

Undang-Undang Republik Indonesia Nomor 2 Tahun 1989 tentang Sistem Pendidikan Nasional.

Undang-Undang Republik Indonesia Nomor 20 Tahun 2003 tentang Sistem Pendidikan Nasional.

Winataputra, Udin S. (2001). Jatidiri Pendidikan Kewarganegaraan Sebagai Wahana Sistemik Pendidikan Demokrasi: Suatu Kajian Konseptual Dalam Konteks Pendidikan IPS. Disertasi PPS UPI: tidak diterbitkan.

Winataputra, Udin S. (2006). Pendidikan Kewarganegaraan dalam Perspektif Pencerdasan Kehidupan Bangsa. Disampaikan pada Temu Sambut Guru Besar FKIP UT. Jakarta: FKIP UT. 